\title{
MED14 Gene
}

National Cancer Institute

\section{Source}

National Cancer Institute. MED14 Gene. NCI Thesaurus. Code C20683.

This gene plays a role in activation of Sp1 transcription. It is also involved in vitamin D and thyroid hormone binding. 